\title{
THE INFLUENCE OF LEADER'S COMPREHENSION ABOUT THE CHURCH'S MANDATE TO THE IMPLEMENTATION OF VISION MISSION OF INDONESIAN BETHEL CHURCH IN SURABAYA
}

\author{
Yunita Stella \\ Evangelical Theological Seminary of Indonesia - Surabaya \\ E-mail: yunitastella@sttii-surabaya.ac.id
}

\begin{abstract}
This research concerns about the Influence of Leader's Comprehension about the Church's Mandate to the Implementation of Vision Mission of Indonesian Bethel Church in Surabaya. The results has shown that the Leader's Comprehension about the Church's Mandate has a significant effect to the Implementation of Vision Mission of Indonesian Bethel Church in Surabaya. A slight reduction or addition of Leader's Comprehension about the Church's Mandate will have a relatively large effect on reducing or increasing the Implementation of Vision Mission of Indonesian Bethel Church in Surabaya. The results of this research indicate that the Leader's Comprehension about the Church's Mandate has an effect of $20.4 \%$ to the Implementation of Vision Mission of Indonesian Bethel Church in Surabaya.
\end{abstract}

Keywords: Leader, Church Mandate, Church, Vision, Mission.

\section{INTRODUCTION}

The church has mandate from God. Regarding to this matter, Dr. Chris Marantika argued that the church has a church's mandate that is the mandate of God Himself to His church, called the Dual Divine Mandate. The church's mandate consists of a Cultural Mandate or a Divine Development Mandate and a Spiritual Divine Mandate or a Divine Renewal Mandate. The first mandate is also known

\footnotetext{
${ }^{1}$ Chris Marantika in Rachmat T. Manullang, Gereja Sekota Yang Mentransformasi Kota (Jakarta : Metanoia, 2003), 26.
}

as the Cultural Mandate. This mandate is related to human physical and mental improvement. Whereas the second mandate is usually known as the Evangelistic Mandate. This mandate relates to the renewal of the spirit and soul of men through the gospel of salvation. ${ }^{1}$ The Cultural Mandate and Evangelistic Mandate are an integral part of the church's work.

The church has the responsibility to carry out both mandates, without sacrificing one mandate to carry out the other mandate. 
Journal Theology (Kerugma)

E-ISSN: 2622-0962

P-ISSN: 2621-8038

But the reality is there are still many churches that only understand their duties in one aspect, the Evangelism Mandate, and lack understanding of the other aspects, namely that the church also has a Cultural Mandate. This can be seen from the understanding of Christians who often separate between things that are spiritual and secular, where spiritual things are ecclesiastical activities such as prayer, worship, cell community and Bible study, while things like activities in politics, economics, entertainment, and so on are worldly matters. As a result, the church has become reluctant to involve itself or to enter the fields of society. Christians are not interested in going to society with an excuse to keep their lives holy, because for them the condition of society is identical with the condition of the world which is evil.

Another thing that is more sad when the church just tends to dwell on its own internal problems; for example, the problem of doctrine, church leaders fighting over power, division, and financial problems that often become triggers of many other problems in the church, so that all of this makes the church forget about the real task.

The church has evangelistic

\footnotetext{
${ }^{2}$ Martin L. Sinaga, Trisno S. Sutantu, Sylvana Ranti Apituley, Adi Pidekso, peny., Pergulatan kehadiran Kristen di Indonesia: Teks-teks Terpilih Eka
}

responsibilities as well as social responsibilities which are an inseparable part of the Christian vision and mission. It is a reflection of the most responsible understanding of the gospel. Man needs the full gospel: for his heart and stomach; for his person and the whole context of his life. ${ }^{2}$ It can be said the problems that exist in society are actually an opportunity for the church to radiate the light of Christ.

Currently in Indonesia there are so many problems that still need to be addressed, including in Surabaya. Surabaya as the second largest city in Indonesia has various problems about the strategic issues of the city. These issues are related to several fields, such as education, health, social, and economics, for instance the high cost of education that is felt by the community, the lack of fulfillment of affordable basic needs and quality health services for the poor, the limited job opportunities resulting a lot of unemployment, crime and various other problems. ${ }^{3}$ The question is whether God's churches in Surabaya can see this as an opportunity to be the answer for community life through the implementation of the vision and mission of the church, or the

Darmaputera (Jakarta: BPK Gunung Mulia. 2005), 415.

${ }^{3}$ Analisis Isu-Isu Strategis. Surabaya: RPJMD Kota Surabaya Tahun 2010-2015, 1-7. 
Journal Theology (Kerugma)

E-ISSN: 2622-0962

P-ISSN: 2621-8038

church just keep silent and does not care about the existing conditions.

DR. Japarlin Marbun as the Chairman of Indonesian Bethel Church Synod has also emphasized that Indonesian Bethel Church in the future must become the church that brings light to the nation and state. ${ }^{4}$ Therefore, the existence of Indonesian Bethel Church in Surabaya is expected to be able to affect the congregation and society through the implementation of its vision and mission.

\section{RESEARCH METHOD}

The research method that be used in this study is a quantitative research method, which explains phenomena in the form of relationships between variables and also be known as correlational research. The relationship between these variables is formulated in a research hypothesis, which will be tested for truth.

The hypothesis in this study: there is an influence of leader's comprehenssion about the church's mandate to the implementation of vision mission of Indonesian Bethel Church in Surabaya. Leader's comprehension about the church's mandate as independent variable (X) and

\footnotetext{
${ }^{4}$ Website: http://reformata.com/news/view/967/pdt.dr.-japarlin-marbun-gbi-perlu-reformasi Senin, 12 Januari 2015.
}

the implementation of vision mission of Indonesian Bethel Church in Surabaya as dependent variable (Y).

Data collection techniques that be used for this study are consists of two instruments in the form of questionnaires that be used by the author, namely to collect data leader's comprehenssion about the church's mandate variable and the implementation of vision mission variable.

\section{RESULT AND DISCUSSION}

From the research that has been done, the researchers get data description about the characteristics of the respondents which are divided into four categories. It is namely based on gender, age, time of ministry and education.

Table. 1

Category of Respondent based on Gender

\begin{tabular}{|c|l|c|c|}
\hline No. & Category & Amount & $\begin{array}{c}\text { Percentage } \\
(\%)\end{array}$ \\
\hline 1. & Man & 63 & 78,75 \\
2. & Woman & 17 & 21,25 \\
\hline \multicolumn{2}{|c|}{ Total } & 80 & 100 \\
\hline
\end{tabular}

In generally, the findings shows the church's leaders are held by men and few of them are led by women. 
Table 2

Category of Respondent by Age

\begin{tabular}{|c|l|c|c|}
\hline No. & Category & Amount & $\begin{array}{c}\text { Percentage } \\
(\%)\end{array}$ \\
\hline 1. & $>70 \mathrm{yrs}$ & 12 & 15,00 \\
2. & $31-40 \mathrm{yrs}$ & 4 & 5,00 \\
3. & $41-50 \mathrm{yrs}$ & 25 & 31,25 \\
4. & $51-60 \mathrm{yrs}$ & 21 & 26,25 \\
5. & $61-70 \mathrm{yrs}$ & 18 & 22,50 \\
\hline \multicolumn{2}{|l|}{ Total } & 80 & 100 \\
\hline
\end{tabular}

The findings show that the church's leadership generally are led by senior leaders, who have already 40 years and above. Only few of them are under 40 years.

Table 3

Category of Respondent based on Time of Ministry

\begin{tabular}{|c|l|c|c|}
\hline No. & Category & Amount & $\begin{array}{c}\text { Percentage } \\
(\%)\end{array}$ \\
\hline 1. & $<5 \mathrm{yrs}$ & 17 & 21,25 \\
2. & $6-10 \mathrm{yrs}$ & 23 & 28,75 \\
3. & $11-15 \mathrm{yrs}$ & 15 & 18,75 \\
4. & $16-20 \mathrm{yrs}$ & 8 & 10,00 \\
5. & $21-25 \mathrm{yrs}$ & 6 & 7,50 \\
6. & $>25 \mathrm{yrs}$ & 11 & 13,75 \\
\hline \multicolumn{2}{|l|}{ Total } & 80 & 100 \\
\hline
\end{tabular}

The findings show that the church's leaders are the experience people in their ministry, but their experience do not identic with their many years of ministry.The findings show the majority of the church's leaders experience are around 6-15 years, but many of them have experienced below 5 years. They might not have a long experience in ministry but they have the ability and special interest so that they can be there church's leaders.

Table 4

Category of Respondent by Education

\begin{tabular}{|c|c|c|c|}
\hline No. & Category & Amount & $\begin{array}{c}\text { Percentage } \\
(\%)\end{array}$ \\
\hline 1. & D3 & 3 & 3,75 \\
\hline 2. & $\begin{array}{l}\text { S1 Non } \\
\text { Theology }\end{array}$ & 16 & 20,00 \\
\hline 3. & $\begin{array}{l}\text { S1 } \\
\text { Theology }\end{array}$ & 21 & 26,25 \\
\hline 4. & $\begin{array}{l}\text { S2/S3 } \\
\text { Non } \\
\text { Theology }\end{array}$ & 3 & 3,75 \\
\hline 5. & $\begin{array}{l}\text { S2/S3 } \\
\text { Theology }\end{array}$ & 16 & 20,00 \\
\hline 6. & Senior HS & 21 & 26,25 \\
\hline \multicolumn{2}{|c|}{ Total } & 80 & 100 \\
\hline
\end{tabular}

The findings show the majority of church's leaders are the people who have theology background. However, to be a church's leader, it can be for someone who took non theology major. Even the table shows that someone who has graduated in senior high school also can be a church's leader. 


\section{Data Analysis}

The calculation utilize SPSS 13.0 program for windows that the result will be shown in this table.

Table 5

Linear Regression Calculation Result

\begin{tabular}{|c|c|c|c|c|}
\hline No. & Variable & Coef. & $\mathrm{t}_{\text {count }}$ & Sig. \\
\hline 1. & The constant & 59,107 & - & - \\
\hline 2. & $\begin{array}{c}\text { The leader's } \\
\text { comprehension } \\
\text { about the } \\
\text { church's } \\
\text { mandate }\end{array}$ & 0,490 & 4,471 & 0,000 \\
\hline \multicolumn{3}{|c|}{$\mathrm{R}=0,452$} \\
$\mathrm{R}^{2}=0,204$ \\
\hline
\end{tabular}

From the calculating of the correlation number $(\mathrm{R})$, there are 0,452 . This number has understanding that the correlation between independent variables which consists of the leader's comprehension about the church's mandate (X) and the implementation of vision mission of Indonesian Bethel Church (Y) is proven in the "average" or "strong enough" position because it is in interval $0,40-0,599$.

Besides that, from the output result about the simple linear regression calculation is known that the big coefficient determination (R2) is 0,204. It has an understanding that the changing of value in an independent variable which is the leader's comprehension about the church's mandate $(\mathrm{X})$ can give explanation how big of the dependent variable about the implementation of vision mission of Indonesian Bethel Church (Y) is $20,4 \%$ and the rest of $79,6 \%$ can be explained by other variables outside the research. It means the independent variables that be used as predictor in this research represent a small dynamic of the leader's comprehension about the church's mandate $(X)$ in affect the implementation of vision mission of Indonesian Bethel Church (Y) that has been researched.

From Table 5 it is known that the statistical calculations get 4.471 with a significance level of 0.000 . This number need to test the leader's comprehension about the church's mandate $(\mathrm{X})$ whether it has a significant effect on the implementation of vision mission of Indonesian Bethel Church (Y). It is because the research findings get $t_{\text {count }}$ of 4,471 supported by a significance value of 0,000 $(p<0.05), H 0$ is rejected or in another word that the leader's comprehension about the church's mandate $(\mathrm{X})$ has a significant effect on the implementation of vision mission of the Indonesian Bethel Church (Y). A slight reduction or addition to the leader's comprehension about the church's mandate will have a relatively large effect on reducing or increasing the Implementation of vision mission of Indonesian Bethel Church in Surabaya. 


\section{CONCLUSION}

The research hypothesis which states "it is suspected that there was an influence of leader's comprehension about the church's mandate to the implementation of vision mission of Indonesian Bethel Church in Surabaya" is proven. This is known from the results of $t_{\text {count }}$ of 4.471 with a significance level of 0.000. In another word, the leader's comprehension about church's mandate significantly influences the implementation of vision mission of Indonesian Bethel Church. Reduction or addition to the leader's comprehension about the church's mandate will have a relatively significant effect on the decline or increase in the implementation of vision mission of Indonesian Bethel Church. This findings reveal that the influence of leader's comprehension about the church's mandate can give portion $20,4 \%$ for the implementation of vision and mission of Indonesian Bethel Church in Surabaya.

The conclusion of this findings are the leader's comprehension will influences his action, especially for the church that be led by him. In this case, the good and correct comprehension from a church's leader about God's mandate will create the implementation of vision and mission of good and correct church. It means the church's leader comprehension will give contribution directly for functioning of a church. When a church's leader has a correct comprehension, he can lead the church that God has trusted for him correctly. Otherwise, when the church's leader has a wrong comprehension, he will lead the church in the wrong way.

\section{REFERENCES}

[1] Achua, Christopher F., Robert N. Lussier. Effective Leadership. Australia: South Western, Cengage Learning, 2010.

[2] Adair, John, John Nelson. Creative Church Leadership. England: Canterbury Press Norwich, 2004.

[3] Andrews, Matt., Jesse McConnell, Alison Wescott. Development as Leadership-led Change: A Report for the Global Leadership Initiative. Washington DC: The World Bank, 2010.

[4] Barclay, William. The Gospel of John. Louisville: Westminster John Knox, 2001.

[5] Barna, George. Leaders On Leadership. Malang: Gandum Mas, 2009.

[6] Barna, George. The Habits of Highly Effective Churches. Malang: Gandum Mas, 2005. 
Journal Theology (Kerugma)

E-ISSN: 2622-0962

P-ISSN: 2621-8038

[7] Clinton, J. Robert. The Making of a

Leader. Colorado Springs: NavPress, 1988.

[8] Coleman, Robert. The Master Plan of Evangelism. Grand Rapids: Revell, 2010.

[9] Daft, Richard L. The Leadership Experience. Australia: South Western, Tomshon, 2008.

[10] Daley, Anthony. The Ekklesia: The Church That Jesus Is Building. Florida: Creation House. 2012.

[11] Dyrness, William. Tema-tema Dalam Teologi Perjanjian Lama. Malang: Gandum Mas, 2013.

[12] Enns, Paul. The Moody Handbook of Theology. Jilid 1. Malang: Literatur SAAT, 2004.

[13] Erickson, Millard J. Teologi Kristen. Malang: Gandum Mas, 2004.

[14] Gnanakan, Ken. Kingdom Concern: A Biblical Exploration Towards a Theology of Mission. Banglore: Theological Book Trust, 1997.

[15] Hiebert, Paul. Evangelism, Church, and Kingdom in The Good News of the Kingdom. New York: Orbis Books, 2003.
[16] Holladay, W. L. A Concise Hebrew and Aramaic Lexicon of the Old Testament: Based upon The Lexical Work of Ludwig Koehler and Walter Baumgartner. Leiden, Netherlands: Brill, 2000.

[17] Kountur, Ronny. Metode Penelitian Untuk Penulisan Skripsi dan Tesis. Jakarta: Percetakan Buana Printing, 2007.

[18] Kristanto, Billy. Ajarlah Kami Bertumbuh. Surabaya: Momentum, 2011.

[19] Landsberg, Max. The Tools of Leadership: Vision, Inspiration, Momentum. London: Harper Collins, 2000.

[20] Lumintang, Pdt. Dr. Stevril I. Misiologia Kontemporer. Batu: Department Multi-Media YPPII, 2006.

[21] Manullang, Rachmat T. Gereja Sekota Yang Mentransformasi Kota. Jakarta : Metanoia, 2003.

[22] Marantika, Chris. Diktat Kuliah. Teologi Pertumbuhan Gereja. Yogyakarta: STTII.

[23] Maxwell, John C. Developing the Leader Within You. Nashville: Thomas Nelson Publishers, 1993. 
[24] McDurmon, Joel. "Is There a

Dominion Mandate? Discussion: The

Dominion Mandate: Yesterday, Today, and

Forever." Answers Research Journal 6, 2013, 145-155.

[25] Meeter, Henry. Pandangan-pandangan

Dasar Calvinisme. Surabaya: Momentum, 2012.

[26] Nanus, Burt. Visionary Leadership.

San Francisco: Jossey-Bass Publishers, 1992.

[27] Nikkel, James R. Church Planting. Canada: Guardian Books, 2004.

[28] Octavianus, P. Identitas Kebudayaan Asia Dalam Terang Firman Allah. Malang : Yayasan Persekutuan Pekabaran Injil Indonesia, 1985.

[29] Oentoro, Jimmy. Gereja Impian: Mejadi Gereja Yang Berpengaruh. Jakarta: PT Gramedia Pustaka Utama, 2010.

[30] Peters, George W. A Biblical Theology of Missions. Malang: Gandum Mas, 2006.

[31] Peters, George W. Teologi Pertumbuhan Gereja. Malang : Gandum Mas, 2013.
[32] Plantinga, Cornelius. Engaging God's World: A Christian Vision of Faith, Learning, and Living. Grand Rapids, MI: William B. Eerdmans Publishing, 2002.

[33] Rainer, Thom. Effective Evangelistic Churches. Nashville: Broadman \& Holman Publishers, 1996.

[34] Rheenen, Van Gailyn. Missions: Biblical Foundations and Contemporary Strategies. Micighan: Zondervan Publishing House, 1996.

[35] Sairin, Pdt. Weinata, M.Th. Visi Gereja Memasuki Milenium Baru. Jakarta: BPK gunung Mulia, 2012.

[36] Sinaga, Martin L., Trisno S. Sutantu, Sylvana Ranti Apituley, Adi Pidekso, peny. Pergulatan kehadiran Kristen di Indonesia: Teks-teks Terpilih Eka Darmaputera. Jakarta: BPK Gunung Mulia. 2005.

[37] Singgih, Emanuel Gerrit, Ph.D., Reformasi dan Transformasi Pelayanan Gereja Menyongsong Abad ke-21. Yogyakarta: Kanisius, 1997.

[38] Southerland, Dan. Transitioning. Malang: Gandum Mas, 2004.

[39] Spykman, Gordon J. Reformational 
Journal Theology (Kerugma)

E-ISSN: 2622-0962

P-ISSN: 2621-8038

Theology: A New Paradigm for Doing

Dogmatics. Michigan: Grand Rapids, 1992.

[40] Stott, John. Isu-isu Global Menantang Kepemimpinan Kristiani. Jakarta: Yayasan Bina Kasih/OMF, 1996.

[41] Sproul, R.C. Kebenaran-kebenaran Dasar Iman Kristen (Malang: Literatur SAAT, 2002), 290.

[42] Spykman, Gordon J. Reformational Theology: A New Paradigm for Doing Dogmatics. Michigan: Grand Rapids, 1992.

[43] Stott, John. Christ the Controversionalist: A Study in Some Essentials of Evangelical Religion. London: Tyndale Press, 1970.

[44] Stott, John. Isu-isu Global Menantang Kepemimpinan Kristiani. Jakarta: Yayasan Bina Kasih/OMF, 1996.

[45] Sugiyono. Metode Penelitian Kuantitatif Kualitatif dan R\&D. Bandung: Alfabeta, 2013.

[46] Suryabrata, Semadi. Metodologi Penelitian. Jakarta: Rajawali Press, 1983.

[47] Thiessen, Henry Clarence. Teologi Sistematika. Malang: Gandum Mas, 2000.
[48] Tomatala, Yakob. Kepemimpinan yang Dinamis. Malang: Gandum Mas, 1997.

[49] Verkuyl, J., Khotbah di Bukit. Jakarta: BPK Gunung Mulia, 2002.

[50] Wagner, C. Peter. Berdoa dengan Penuh Kuasa. Jakarta: Nafiri Gabriel, 2001.

[51] Wagner, C. Peter. Church Growth and the Whole Gospel: A Biblical Mandate. Oregon: Wipf \& Stock, 1998.

[52] Wagner, C. Peter. Gereja yang Berdoa. Yogyakarta: Yayasan ANDI, 1993.

[53] Wagner, C. Peter. Strategi Perkembangan Gereja. Malang: Gandum Mas, 1996.

[54] Warren, Rick. Purpose Driven Church. Malang: Gandum Mas, 2012.

[55] Website: http://reformata.com/news/ view/967/pdt.-dr.-japarlin-marbun-gbiperlu-reformasi Senin, 12 Januari 2015.

[56] Woga, Edmund. Dasar-dasar Misiologi. Yogyakarta: Kanisius, 2002.

[57] Wolters, Albert M. Pemulihan Ciptaan. Surabaya: Momentum, 2010. 